\title{
"Ale cóż ma począć poeta, jeśli nie może wyrażać litości i grozy?" Korespondencja Czesława Miłosza i Anny Kowalskiej z lat 1948-1950
}

Ewa Kołodziejczyk

TEKSTY DRUGIE 2019, NR 3, S. 353-366

DOI: 10.18318/td.2019.3.21 | ORCID: 0000-0003-1182-7313

1.

Wrocław, 23.I.1948 roku

\section{W Pan}

Czesław Miłosz

W a r s z a w a

Min. Spraw Zagranicznych.

"Zeszyty Wrocławskie” zamierzają wydać numer specjalny z powodu Wystawy Ziem Odzyskanych, która zostanie otwarta we Wrocławiu dnia 1.VII.1948 roku. W intencji redakcji numer ten będzie stanowił przegląd wybitnych sił literackich współczesnych, szczególnie zaś ukaże się twórczość pisarzy, którzy zapragną w ten sposób zaświadczyć swoją postawę wobec potrzeb środowiska literackiego we Wrocławiu.

Nie wysuwając żadnych propozycji co do tematów, redakcja "Zeszytów Wrocławskich” prosi o nadsyłanie materiałów, nieprzekraczających 3 stron maszynopisu (proza artystyczna i krytyczna, poezje, ewentualnie

\section{Czesław Miłosz}

(1911-2004) - polski poeta, prozaik, eseista, tłumacz, historyk i krytyk literacki; laureat literackiej nagrody Nobla; w latach 1946-1950 przebywał w Stanach Zjednoczonych jako członek polskiej misji dyplomatycznej.

\section{Anna Kowalska} (1903-1963) - polska pisarka i diarystka, współredaktorka "Zeszytów Wrocławskich". 
przekłady) w terminie do 20.V.1948 roku pod adresem Wrocław, Plac Nankiera 7.

Artykuły będą honorowane.

Redakcja „Zeszytów Wrocławskich” posiada nadzieję, że dla numeru wydawnictwa, który będzie manifestacją polskiej kultury literackiej na Ziemiach Zachodnich, zdoła pozyskać pióra najświetniejsze.

\section{Tadeusz Mikulski, Anna Kowalska}

List napisany na maszynie, jednostronnie na kartce papieru firmowego z nadrukiem: Zeszyty Wrocławskie, Kwartalnik Krytyczno-Literacki, Redakcja i Administracja, Wrocław, Plac Biskupa Nankiera 7 m.4. Między listem a podpisami nadawców pieczęć „Zeszyty Wrocławskie” / Redakcja / Wrocław / Pl. Biskupa Nankiera 7. Koperta zachowana: recto - adres odbiorcy: Monsieur / Czesław Miłosz / Polish Ambassy [sic!] / Washington D.C. 2640 / 16th Street N.W. / United States of America; na kopercie w prawym dolnym rogu odręczny dopisek granatowym ołówkiem: Tak adresuje Poselstwo RP w Bernie! Poza tym list prywatny - nie rejestruję; tym samym ołówkiem podkreślony podwójnie wyraz Ambassy; verso - adres nadawcy: LÉGATION DE LA REPUBLIQUE DE POLOGNE A BERNE.

Czesław Miłosz

914 Sheridan st. N.W.

Washington D.C.

Szanowna Pani,

Z opóźnieniem doszła do mnie wiadomość o śmierci Jerzego Kowalskiego'. Bardziej, niż umiałbym to wyrazić w liście, odczuwam, jak wielka to strata i dla Pani, i dla naszego kraju. Niech te krótkie kondolencje wystarczą za wyraz moich uczuć.

1 Jerzy Kowalski (1893-1948) - filolog klasyczny, pisarz, tłumacz, profesor uniwersytecki, członek Polskiej Akademii Umiejętności. Czesław Miłosz poznał Annę i Jerzego Kowalskich podczas okupacji. Zob. A. Kowalska Dzienniki 1927-1969, przedm. J. Hartwig, przygot. do druku, przyp. P. Kądziela, Wydawnictwo Iskry, Warszawa 2008, s. 78-79. 
Często myślałem o Jerzym Kowalskim i o Pani. Pewni ludzie trwają w naszej pamięci nie okresami, ale stale, równocześnie z przypływem nowych doświadczeń.

Otrzymałem numer „Zeszytów Wrocławskich” z pracą Mikulskiego i rozprawą o Montaigne'u². Chciałbym bardzo, aby dzieła Jerzego Kowalskiego mogły jak najszybciej ukazać się w formie książkowej. Sądzę, że jego przekłady są w Polsce w a ż n e.

Trzykrotnie bodaj wysyłałem jakieś książki dla Pani i Marii Dąbrowskiej3. Ostatnie zdaje się w czerwcu, adresując na Polną . "Zeszyty Wrocławskie” są zdaje się bardzo dobre. Otrzymałem zaproszenie do współpracy dziwną drogą, bo nadesłane z naszego poselstwa w Bernie ${ }^{5}$. Niestety jestem bardzo przeciążony pracą i nie wiem, kiedy będę mógł z zaproszenia skorzystać. Nie wiem, czy „Zeszyty” drukują np. wiersze.

Składam szczere wyrazy gorącej sympatii w imieniu swoim i żony, która chwilowo jest poza Waszyngtonem

\section{Czesław Miłosz}

August 23, 48

List napisany na maszynie, jedna kartka, na papierze firmowym z nadrukiem: Czesław Miłosz / 914 Sheridan st. N.W. / Washington D.C.; podpis i data zapisane odręcznie czarnym atramentem; koperta nie zachowała się.

2 Mowa o numerze 2 "Zeszytów Wrocławskich" z 1948 r., w którym ukazały się podzwonne Jerzy Kowalski (s. 3-8) Tadeusza Mikulskiego i szkic Jerzego Kowalskiego o Montaigne'u pt. U bram znanych iświetnych (s. 9-17).

3 Z korespondencji Marii Dąbrowskiej i Anny Kowalskiej wynika, że Miłosz przesyłałksiążki kurierem dyplomatycznym do MSZ w Warszawie. Były to m.in. wydawnictwa Penguin Books, wśród nich np. Tortilla Flat Steinbecka, Babbit S. Lewisa i A Tree grows in Brooklyn Betty Smith, komiksy, słownik A Treasury of Synonyms and Antonyms oraz słownik języka angielskiego wydawnictwa Webster. Za tę informację dziękuję profesor Ewie Głębickiej.

4 Maria Dąbrowska mieszkała przy ul. Polnej 40 w Warszawie.

5 Bernie - zob. metryczkę listu nr 1. 


\section{3.}

Wrocław, 7.11.1948

Drogi Panie Czesławie, dziękuję za pamięć, kondolencje z okazji śmierci mego męża i za przyjazne słowa. Przygotowuję do druku kilka tomów prac Jerzego: wiele jeszcze czeka na odczytanie i przepisanie. Dołożę starań, aby nic z tego, co wartościowe, nie zmarniało $\mathrm{w}$ niepamięci.

Mieszkam z dwuletnią córeczką ${ }^{6} \mathrm{w}$ brzydkiej, ale wygodnej willi na przedmieściu. Mam tysiąc książek, trzydzieści drzew owocowych, dwie służące i jedną parę butów. Wynika, że jestem łasa na książki i wolny czas. Otrzymałam od Pana dwie przesyłki książek, trzecią dostała p. Maria․ Najbardziej podobały mi się Tortilla Flat ${ }^{8}$ i książka W. Saroyana'. Bardzo jestem Panu za nie wdzięczna.

Jeśli znajdzie Pan czas, proszę przysłać do „Zeszytów”, na mój prywatny adres, prozę albo wiersze.

Na Polnej czytaliśmy z przejęciem Traktat moralny ${ }^{10}$. Rzadko jaki utwór wywołał tyle zachwytu u jednych i ubolewania u Eleuterydów ${ }^{11}$.

Proszę przypomnieć mnie żonie i przyjąć najlepsze pozdrowienia dla obojga Państwa

Anna Kowalska

Wrocław, Karłowice

Ul. Lindego, 10

List odręczny, jedna kartka zapisana obustronnie czarnym atramentem. Koperta zachowana: recto - adres odbiorcy: Czesław Miłosz / 914 Sheridan st. N.W. /

6 Mowa o Marii, córce Anny i Jerzego Kowalskich, ur. 1946, przez bliskich nazywanej Tulcią.

7 Mowa o Marii Dąbrowskiej.

8 Tortilla Flat - powieść Johna Steinbecka z 1935 r.

9 Być może mowa o bestsellerowej powieści The Human Comedy Williama Saroyana z 1943 r.

10 Traktat moralny został opublikowany w "Twórczości" $1948 \mathrm{nr} 4$.

11 Eleuterydów - aluzja do czterech Listów do Felicji Jarosława Iwaszkiewicza opublikowanych pod pseudonimem Eleuter (Traktat moralny, "Nowiny Literackie” $1948 \mathrm{nr} 33$, s. 7; Najgorsza jest niepewność, "Nowiny Literackie" 1948 nr 37, s. 7; Jeszcze o "Traktacie moralnym", "Nowiny Literackie" 1948 nr 40, s. 7; O przyjaźni, "Nowiny Literackie" 1948 nr 43, s. 7). 
Washington D.C. / U.S.A.; stempel: Wrocław; verso - adres nadawcy: Anna Kowalska / Polska, Wrocław, Karłowice / ul. Lindego 10; stempel: Warszawa 2 11.11.48.

\section{4.}

[13 I 1950]

Droga pani Anno,

mam sprawę następującą: wychodzi wkrótce w New Yorku księga o Mickiewiczu, po angielsku, pod redakcją Kridla i Wittlina ${ }^{\mathbf{1 2}}$. Magna pars $^{\mathbf{1 3}}$ tego i ja kręcę. Dajemy tam przekłady na angielski fragmentów różnych pism Mickiewicza i głosy o Mickiewiczu zagranicznych i polskich pisarzy i uczonych. Jest to impreza poniekąd oficjalna, bo firmuje ją katedra im. Mickiewicza na Columbia, subsydiowana przez rząd ${ }^{14}$. Otóż do tej księgi potrzebny jest artykuł Jakóbca z „Zeszytów Wrocławskich” pt. Słowacki w kręgu Puszkina ${ }^{15}$. Tytuł musimy zmienić, dodać też objaśnienia, ale jest to chyba najlepszy artykuł wprowadzający in medias res ${ }^{16}$ stosunków Puszkina z Mickiewiczem. Występuję więc teraz jako Ambasada i proszę o zezwolenie na przekład, zmianę tytułu i druk. Możemy wypłacić honorarium, jeżeli trzeba. Prośbę moją niech pani będzie łaskawa zakomunikować Jakóbcowi jako urzędową.

Teraz o sobie, jako że mam pani życzliwość. Niedobry to dla mnie rok, a serce moje jest ciężkie - mówiąc bezwstydnie. Tłumaczę Otella ${ }^{\mathbf{1 7}}$, a poza tym uczucie człowieka o związanych nogach i rękach. Dużo czytam - np. m.in. odkryłem, że jest brzydka rzecz w naszej literaturze - nie zajmują w niej żadnego miejsca przekłady z literatury żydowskiej, która powstała na terenie

12 którą objął Manfred Kridl po odejściu Arthura Colemana. Zob. Cz. Miłosz „Mój wileński opiekun”. Listy do Manfreda Kridla (1946-1955), z uzupełnieniem o listy Manfreda Kridla i addendum, przygot. do druku, wstęp, przyp., nota edytorska A. Karcz, Wydawnictwo UMK, Toruń 2005.

Mowa o edycji Adam Mickiewicz. Poet of Poland. A Symposium, ed. by M. Kridl, Columbia University Press, New York 1951.

magna pars (łac.) - w dużej mierze, dużą część.

M. Jakóbiec Słowacki w kręgu poetyckim Puszkina. Na tropach rozwiq̨zania jednej zagadki, „Zeszyty Wrocławskie" $1949 \mathrm{nr}$ 1/2, s. 3-12.

16 in medias res (łac.) - od razu do rzeczy, w środek spraw.

W „Twórczości” 1950 nr 7 ukazał się akt I Otella w przekładzie Czesława Miłosza. 
Polski, i trzeba dopiero przyjechać do Ameryki, żeby ją odkryć. Poza tym zajmuję się automobilizmem, chodzę na serię pokazów historii filmu od 1903 roku $^{18}$ (to są rzeczy zdumiewające, ten smak przemian półwiecza) i chodzę do jedynego teatru w Waszyngtonie, tj. do burlesque - znów dziwna sprawa, której nigdzie poza Ameryką nie można zobaczyć - jest to przedstawienie czystej ordynarności, niezabarwionej w najlżejszym stopniu sentymentalizmem, coś w rodzaju ludowego pornograficznego cyrku (a czym jest ostatecznie Lizystrata Arystofanesa ${ }^{19}$ ?). Syn mój rośnie i gada w dwóch językach ${ }^{20}$. Bardzo pani dziękuję za przysłanie opowieści greckich²1.

Serdecznie pozdrawiam

Czesław Miłosz

P.S. Czy „Zeszyty” nadal wychodzą? Ciągle przymierzam się coś tam napisać. Ale o czym. Nie byłaby pani zadowolona z ody na cześć Einsteina ${ }^{\mathbf{2 2}}$, z osobistej znajomości z którym jestem bardzo dumny. Uczeni bułgarscy nazywający go obskurantystą ${ }^{23}$ nie mają niestety racji. Właśnie ogłosił ukoronowanie dzieła

18 Miłosz wspominał (Obyczaje, „Zeszyty Wrocławskie” $1950 \mathrm{nr}$ 1/2, s. 80): „W tymże miesiącu styczniu 1950 roku chodziłem na cykl pokazów filmowych, przedstawiających historię filmu od jego początków. Widziałem pierwsze niemieckie obrazki ruchome, Życie strażaka amerykańskiego (1903), fragmenty innych starych filmów amerykańskich, niemiecką komedię Niezrozumiany (1912), krótkie komedie Chaplina, komedię Mężczyzna i kobieta w reżyserii Cecila B. DeMille'a, z Glorią Swanson (1919), niemiecką komedię Małżeństwo Don Juana (1919), impresjonistyczny reportaż z Paryża Tylko godziny Cavalcantiego (1926). Widziałem też obrazy szczególnie wsławione w historii sztuki filmowej: Gabinet doktora Caligari w reżyserii Roberta Wiene, z Kraussem, Veidtem i Lil Dagover (1919), Słomkowy kapelusz René Claira, z Préjeanem (1927) i Pasje Joanny d'Arc Dreyera, z aktorką Falconetti (1929)".

19 Lizystrata Arystofanesa - komedia powstała w 411 r. p.n.e., w czasie II wojny peloponeskiej. Jej intryga osnuta jest wokół ultimatum żon, które odmawiają mężom współżycia do chwili zawarcia przez nich pokoju.

Antoni Oskar, ur. 1947, pierwszy syn Janiny i Czesława Miłoszów.

Mowa o Opowiadaniach greckich Anny Kowalskiej, opublikowanych w 1949 r. przez wydawnictwo Czytelnik.

Mowa o wierszu Do Alberta Einsteina, ukończonym w 1949 r. i publikowanym we fragmentach w kolejnych edycjach poezji Miłosza: Cz. Miłosz Wiersze, Wydawnictwo Literackie, Kraków 1985, t. 1, s. 279-280; tegoż Wiersze, t. 2, Znak, Kraków 2002, s. 147-148. Inną wersję utworu zawiera zbiór Cz. Miłosz Wiersze i ćwiczenia, do druku podał, wstęp M. Skwarnicki, Świat Książki, Warszawa 2008, s. 114-121, natomiast w tomie Cz. Miłosz Wiersze wszystkie, Znak, Kraków 2011, s. 360-361 przypomniana jest wersja z wydań z 1985 i 2002 r.

23 Nie udało się ustalić, o czyją wypowiedź chodzi. 
swego życia - równania stanowiące „klucz do wszechświata”, dowodzące tożsamości grawitacji i elektromagnetyzmu, tj. dające to samo wytłumaczenie dla makrokosmosu i mikrokosmosu²4. Jest to wielkie stulecie, bo spełniły się kabalistyczne oczekiwania alchemików. Moja druga i ukryta natura „ucznia czarnoksiężnika” (bez czego praktykowanie poezji jest niemożliwe) bardzo się raduje. „Alchemia słów” była mi zawsze wstrętna ${ }^{25}$, bo jest alchemia prawdziwa. I jest wielkość prawdziwa - Kopernika, Newtona i Einsteina. Ale cóż ma począć poeta, jeśli nie może wyrażać litości i grozy?

List odręczny, dwie kartki, jedna zapisana obustronnie czarnym atramentem; koperta zachowana: recto - adres nadawcy w lewym górnym rogu: Czesław Miłosz / Polish Embassy / 2640 16th STSEET [sic!] N.W. / Washington D.C; adres nadawcy: Poland / Anna Kowalska / ul. Lindego 10 / Wrocław - Karłowice; stempel: Washington D.C. Jan 131950 11-PM; verso - trzy stemple: dwa jednakowe Poznań 2 19.1.50 oraz Warszawa 2 20.1.50.

5.

Wrocław, 3.II.50

Drogi Panie Czesławie,

dziękuję za list tak dla mnie ciekawy. Przypisek przypomina najlepsze partie Candide'a. Prosimy koniecznie o jakiś artykuł, esej, a jeśli możliwe, wiersz. Sam Pan najlepiej wie, co jest - druk-able ${ }^{26}$. „Zeszyty” wychodzą, wprawdzie w trochę zwolnionym tempie, ale jest nadzieja, że staniemy się bardziej

24 Miłosz może mieć na myśli artykuł Einsteina On the Generalized Theory of Gravitation, "Scientific American" April 1950 lub też wznowienie jego książki The Meaning of Relativity (prwdr. Princeton University Press, Princeton 1945); w jej trzecim wydaniu, z 1950 r., Einstein umieścił dodatek, w którym przedstawił uogólnioną teorię grawitacji.

25 Aluzja do drugiego rozdziału Une Saison en Enfer Arthura Rimbauda pod tytułem Alchimie du verbe (prwdr. 1873, tłum. pol. S. Miłaszewski, 1915). Sezon w piekle ukazał się w antologii Stefana Napierskiego Od Baudelaire'a do nadrealistów. Przekłady i szkice nowoczesnej literatury francuskiej, Wydawnictwo Gebethner i Wolff, Warszawa 1933, w której przypomniano tylko cztery wiersze z Alchemii słowa w przekładzie Miłaszewskiego - pozostałe podano w tłumaczeniu Napierskiego. 
sprężyści. Proszę możliwie s zy b ko nam przesłać i podać sposób przesłania honorarium.

Pracuję nad wieloma rzeczami naraz. Najwięcej kłopotu sprawia mi kolacjonowanie Wykładów Lozańskich w opracowaniu moim dla wydania narodowego ${ }^{27}$.

Czytam Horacego, zastanawia mnie, co właściwie oznacza ów prostaczek czekający dusz defluat amnis ${ }^{28}$. Sielanki Wergilego w ostatnim wydaniu wydały mi się najprzewrotniejszym rodzajem literackim.

Ciekawe byłoby studium o tym, jak różne epoki czytały klasyków. Myślę, że jeśli poeta nie może opiewać litości i grozy, ostatecznie może napisać Eneidę. Zaklnie Pan w tym miejscu?! Ale czy nie dziwne, że Dante (a ten się lubował w grozie!) właśnie wybrał klarownego altissimo poeta ${ }^{29}$ za przewodnika.

Tulcia poluje „w jaskinicy na drapieżne motyle” i usypia „książki w kolebusi, aby i one czasem sobie odpoczęły”. Nie lubi nieba: „Co warte niebo, jeżeli nikt z niego nie wraca. Nawet jak się zmęczę uważaniem na to, żebym była grzeczna i aż się kładę na dywanik - tato nie przychodzi z tego nieba nawet na chwilę. Cóż mi z nieba?".

Oto kronika. Serdecznie Pana pozdrawiam i Jego rodzinę

Anna Kowalska

P.S.: Na kopercie przysłanego listu jest błąd STSEET ${ }^{30}$. Nie powinno tego być. Spodziewam się, że dostał Pan list dr. Jakóbca.

List odręczny, jedna kartka zapisana obustronnie zielonym atramentem. Koperta nie zachowała się.

27 Wykłady lozańskie - w szesnastotomowym wydaniu narodowym pism Adama Mickiewicza lozańskie prelekcje poety ukazały się w tomie 7: Pisma prozą. Cz. 3. Pisma historyczne; Wykłady lozańskie, oprac. J. Kowalski i L. Płoszewski, Czytelnik, Warszawa 1950.

28 ów prostaczek czekający dusz defluat amnis (łac.) - właśc. Rusticus expectat dum defluat amnis; at ille labitur et labetur in omne volubilis cevum; aluzja do I księgi Listów Horacego („Ten, kto odkłada godzinę rozpoczęcia prawego życia, przypomina wieśniaka, który czeka, aż cała rzeka przepłynie, zanim ją przekroczy. Lecz ona płynie i będzie płynąć bez końca").

29 altissimo poeta (łac.) - najwspanialszy poeta; aluzja do pochwały Wergiliusza onorate l'altissimo poeta ("uczcijcie największego poetę") z Boskiej komedii Dantego.

30 Zob. metryczkę listu 4. 
6.

15 luty 1950

Droga Pani Anno,

za kilka dni wyślę materiały do „Zeszytów Wrocławskich”, tylko muszę uporać się z koncertem ${ }^{31}$, otwarciem wystawy ${ }^{32}$ i odczytem ${ }^{33}$, które się spiętrzyły. Myślę posłać szkic pt. Obyczaje pótwiecza ${ }^{34}$ na podstawie sztuk teatralnych i filmów - jeżeli nie druk-able, to Pani przynajmniej przeczyta. Ja nie wiem już naprawdę, co Pani się nada. Oto propozycje:

1) Przekład Otella. Czy zmieściłby się cały akt? Czy Szekspir jest mangeable ${ }^{35}$ ? Nie jest to co prawda pisarz bardzo wybitny, a i babki miał nie w porządku.

2) Szkic o Szekspirze - głównie analiza ekonomicznych przemian jego czasów i jego statusu życiowego - o tym u nas nie pisano prawie.

3) Przekłady bajek (folklor) w Polsce nieznanych. Folklor Żydów polskich? Murzyński? Egipski? (prozą).

4) Wolne przekłady z poetów starożytnych (ale zasadniczo wg tekstu angielskiego).

5) Wiersze własne - choć z tym bieda.

6) Sugestie pani.

Przeczytałem największą rozmiarami książkę napisaną dotychczas o okupacji niemieckiej w Polsce. Jest to powieść o getcie warszawskim, napisana przez Johna Herseya, autora Hiroszimy ${ }^{36}$ - The Wall³7. Przyślę ją pani, jak się

31 Nie udało się ustalić, o jaki koncert chodzi.

32 Mowa o wystawie obrazów dzieci polskich zorganizowanej w Ośrodkach Kultury Plastycznej. Por. list 7 .

Mowa o odczycie, który poeta wygłosił 27 lutego 1950 r. na Uniwersytecie Columbia, na zaproszenie Manfreda Kridla. Zob. E. Kołodziejczyk Amerykańskie powojnie Czesława Miłosza, Wydawnictwo IBL PAN, Warszawa 2015, s. 160-172.

Artykuł pt. Obyczaje ukazał się w "Zeszytach Wrocławskich” 1950 nr 1/2, s. 78-90.

mangeable (franc.) - zjadliwy, do przełknięcia.

36 Hiroshima - reportaż pisarza i dziennikarza Johna Herseya (1914-1993). Złożyło się nań sześć świadectw osób ocalałych po zrzuceniu bomby atomowej na Hiroszimę. Reportaż wypełnił cały numer tygodnika "The New Yorker" z 31 sierpnia 1946 r., co było precedensem w historii prasy amerykańskiej. Został wydany w formie książki jeszcze w tym samym roku (wyd. pol. w przekł. Józefa Wittlina, 1948, oraz w przekł. Jerzego Łozińskiego, 2013). 
ukaże w księgarniach, bo mam tylko egzemplarz od autora. Pożarłem jej ponad 600 stron natychmiast, jest to książka wstrząsająca, a dokumentacja bardzo staranna, na ogół. Pisana w formie pamiętnika odkopanego w gruzach getta po wojnie. Silne akcenty syjonistyczne.

\section{Pozdrawiam Panią i córkę}

Czesław Miłosz

P.S. Załączam artykuł Obyczaje. Wiersze za parę dni.

List odręczny, jedna strona zapisana czarnym atramentem; data 9 luty skreślona, pod nią poprawiono na 15 luty; koperta nie zachowała się.

Droga Pani Anno, Przesyłam w załączeniu 3 wiersze do „Zeszytów Wrocławskich"38. Zostawiam Pani uznaniu, czy wydrukować je wszystkie, czy i co wybrać. Zasadniczo nie lubię rozsuwać po jednym wierszu, ale powtarzam, zdaję się na sąd Pani niech Pani wydrukuje to, co przypadnie Pani do smaku. Tydzień temu wysłałem artykuł czy esej Obyczaje.

Jeżeli pani to odpowiada, chciałbym nawiązać żywszy kontakt z „Zeszytami". Tygodniowe pisma literackie mają coraz bardziej charakter gazet, a „Twórczość” właściwie też, z tą różnicą, że jest tam większa porcja złych wierszy złych poetów. Życzyłbym „Zeszytom”, żeby mogły się ukazywać jako miesięcznik, bo właściwie przy tej obfitości drukowanego papieru, nie ma gdzie drukować.

Przesyłam pozdrowienia

Czesław Miłosz

dzie autora. O zgodę na wykorzystanie tego fragmentu Hersey prosił Miłosza w liście z 10 października 1949 r. (Czesław Miłosz Papers, Beinecke Rare Book and Manuscript Library, Series 1 Correspondence, Box 26, Folder 407).

38 Mowa o wierszach Narodziny, Do Tadeusza Różewicza, poety oraz Warsztat grafiki ludowej (El Taller de Gràfica Popular), które ukazały się W "Zeszytach Wrocławskich" 1950 nr 1/2, s. 64-69. 
23. II. 50

P.S. Zrobiłem bardzo ładną wystawę obrazów malowanych przez polskie dzieci w Ośrodkach Kultury Plastycznej. Te obrazy są lepsze od tych, jakie tu można widzieć. Co za zdolny naród! Za zdolny, myślę i troszczę się. Wystawa bardzo się podobała.

Co do wiersza do Różewicza, to posyłam go w pierwszej redakcji i u p o w a ż n i a m Panią, znając exquisite taste ${ }^{39}$, albo do wydrukowania jak jest, albo do wydrukowania tylko jednej strony tego wiersza i pominięcia tego, co jest na następnej, bo może te uszczypliwości są niepotrzebne (względnie wyrzucenia tego wiersza w ogóle). Trudno mi o właściwe proporcje, pani łatwiej to wyczuć.

\section{CM}

List odręczny, jedna kartka, zapisany obustronnie czarnym atramentem; koperta nie zachowała się.

8.

Droga Pani Anno,

Pytała mnie Pani, jak zatytułować artykuł. Otóż najlepiej tak jak jest, tj. Obyczaje. Co do wierszy, to prosiłem, żeby Pani wyrzuciła te, które pani zdaniem są mniej przydatne. Mówi pani, iż chciałaby pani wiersze mniej ezoteryczne. Zgadzam się z tym żądaniem. Więc wie Pani, niech Pani lepiej wyrzuci ten wiersz do Różewicza. Bo ten jest ezoteryczny. Ja ciągle, wstyd powiedzieć, eksperymentuję. Ale Warsztat grafiki ludowej nie jest ezoteryczny. Chciałbym, żeby Pani go dała jako pierwszy, jako drugi ten wiersz o narodzinach, a do Różewicza wyrzucić. Przepraszam, że nadużywam Pani uprzejmości. Dużo myślę i borykam się. Nie mogę już patrzeć na ten kraj, to jest dom wariatów. Jednak te lata pobytu w Ameryce były dla mnie decydujące. Jak - to się jeszcze okaże. W każdym razie mam dużą wiedzę o tym kraju, a jest to wiedza dość miażdżąca.

Przesyłam serdeczne pozdrowienia 
List odręczny, jedna kartka, zapisany obustronnie czarnym atramentem; koperta nie zachowała się.

9.

Wrocław, 15.IX.1950

Drogi Panie Czesławie, numer „Zeszytu Wrocławskiego” z Pana wierszami i Obyczajami nareszcie gotów. Wyślemy go w najbliższym czasie. Proszę donieść, w jaki sposób życzy sobie Pan, aby przesłać honorarium. Zamykamy rachunki tego numeru. Oczekujemy wierszy i artykułów. Składamy następny numer.

Czy otrzymał Pan Rozwój cywilizacji greckiej ${ }^{40}$ mego męża, który wysłałam?

Od naszego ostatniego widzenia zdaje się, że upłynęły... eony. Pracuję dużo. Utrzymać sześć osób ${ }^{41}$, i to z literatury, to nie bagatelka, ale optymizm rodziny jest niezachwiany i niepohamowany. Moja czteroletnia córka niepokoi mnie swoim dowcipem. Też się wybrała!

Serdecznie Pana i Jego rodzinę pozdrawiam i proszę o rychłe wiadomości

\section{Anna Kowalska}

List odręczny, jedna kartka złożona na pół i zapisana jednostronnie czarnym atramentem. Koperta zachowana: recto - adres odbiorcy: Czesław Miłosz / Washington / D.C. / 914 Sheridan St. NW / U.S.A.; stempel listu poleconego: R Wrocław / Nr 2362; nad adresem naklejka: LOTNICZA / PAR AVION; verso - adres nadawcy: A. Kowalska / Wrocław / Lindego 10; dwa stemple polskie: Wrocław 16.9.50 i Warszawa 2 17.9.50; trzy stemple amerykańskie: Washington D.C. 18 SEPT 1950, 19 SEPT 1950, 20 SEPT 1950

40 Rozwój cywilizacji greckiej - studium Jerzego Kowalskiego z przedmową Bronisława Bilińskiego, wydane pośmiertnie we Wrocławiu, w Książnicy Atlas, w 1950 r.

41 Aluzja do sytuacji rodzinnej Anny Kowalskiej, w domu której okresowo oprócz służącej i opiekunki Tulci mogli mieszkać: Wojciech Ostrowski, siostrzeniec (ur. 1932), syn zmarłej Zofii z Chrzanowskich (1912-1948), oraz wdowa po bracie Ignacym (1905-1944), Maria Chrzanowska (mieli syna Adama, ur. 1938). Za tę informację dziękuję profesor Ewie Głębickiej. 
10.

[jesień 1950]

\section{Miłosz}

47, rue Dumont - D'Urville

Paris XVIe

Droga Pani Anno,

dostałem Pani list, ale nie odpowiedziałem, bo miałem zawrócenie głowy z wyjazdem do Europy. Jestem teraz w Krakowie, tfu, przepraszam, pomyliłem się, w Paryżu ${ }^{42}$. Myślę, że za parę tygodni przyjadę do Warszawy, ale nie wiem, czy będę miał dość czasu, żeby odwiedzić Wrocław. Będę wdzięczny, jeżeli przyśle mi Pani jeden numer „Zeszytów Wrocławskich” do Paryża. Honorarium na adres: Henryka Goszczyńska, Państwowe Zakłady Wydawnictw Szkolnych, ul. Kredytowa, Warszawa (to siostra mojej żony).

\section{Bardzo serdecznie Panią i dowcipną (o rety) córkę pozdrawiam}

Czesław Miłosz

List odręczny, jedna kartka, zapisana obustronnie czarnym atramentem; koperta nie zachowała się.

Podstawa publikacji to oryginały listów Anny Kowalskiej i Czesława Miłosza. Cztery listy Anny Kowalskiej przechowywane są w Beinecke Rare Book and Manuscript Library w Yale University w New Haven (Czesław Miłosz Papers, Series 1 Correspondence, Box 1, Folder 37), sześć listów Czesława Miłosza - w Muzeum Literatury im. Adama Mickiewicza w Warszawie (tom III Korespondencji A. Kowalskiej k. 52-58. Nr inw. 1013).

Przygotowując listy do druku, uwspółcześniono i ujednolicono ortografię oraz uzupełniono interpunkcję. Zachowano autorskie zapisy dat i miejsc oraz niekonsekwencje w zapisach zwrotów grzecznościowych (np.„pani”/„Pani”)

42 Miłosz opuścił Stany Zjednoczone 28 września 1950 r., a z 5 października objął funkcję I Sekretarza do spraw kulturalnych w Ambasadzie RP w Paryżu. 
i konwencji epistolarnych (wielka litera po przecinku w nagłówku listu). Nie poprawiano ani nie ujednolicano pisowni nazw własnych. Poprawiono i uwspółcześniono pisownię oraz odmianę nazwisk obcych. Utrzymano zapis „New York” jako właściwość stylu Czesława Miłosza. Poprawiono literówki, błędy ortograficzne i rozwinięto zapisy skrótów „b.” (bardzo, były), „ew.” (ewentualnie), „r.” (rok), ,kkt.” (który), „Wwy” (Warszawy). Daty i miejsca znajdujące się na stemplach pocztowych oraz inne informacje pozwalające datować korespondencję umieszczono w metryczkach pod listami. Utrzymano zapisy liczebników w formie cyfr. Tytuły tekstów literackich oraz słowa i zwroty obcojęzyczne zapisano kursywą. W transkrypcji adresów na kopertach i w tekstach listów zachowano podkreślenia i kapitaliki.

Podziękowania za udzielenie zgody na publikację korespondencji zechcą przyjąć Pan Cezary Gawryś oraz Pan Antoni Miłosz.

\section{Ewa Kołodziejczyk}

\section{Abstract}

\section{Czesław Miłosz}

\section{Anna Kowalska}

"What is a Poet to Do, Being Unable to Express either Pity or Horror?"The Correspondence between Czesław Miłosz and Anna Kowalska, 1948-1950

The writers Czesław Miłosz and Anna Kowalska met during World War II, and the letters they exchanged in the years 1948-50 represent a continuation of their acquaintance. Their main function was to exchange information, for instance on the publication of the work Miłosz submitted to Zeszyty Wrocławskie, a quarterly of which Kowalska was an editor; topics also include Miłosz's writing and cultural work in the United States and the two writers' respective family lives, especially Kowalska's, who was recently widowed. In his letters to Kowalska Miłosz makes rare allusions to his increasingly difficult situation as a poet involved in the diplomatic service at a time when Poland's politics of culture were becoming more restrictive. Their correspondence testifies to a dialogue between two connoisseurs and lovers of literature who held each other in high esteem.

\section{Keywords}

postwar literary culture, Polish diaspora in the USA, Zeszyty Wrocławskie, reception of Traktat moralny [Treatise on Morality] 